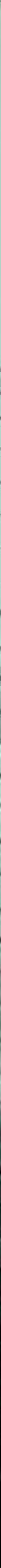





\section{TECHNICAL, PAPEAR}

CORRELATION BETWEEN CONCPETE DURABILITY AND

AIR-VOID CHARACTERISTICS

TO: Z. B。 Woods, Director

Jolnt Highway Rosearch Projoct Docersor 18, 1957

FROM: Ho Lo Kichael, Assistant Director

F110: $5-8-17$

Project $\cos 36-3 \%$

The attached tochn1cal paper ent1tled, "Correlation Botwaen Concrete Durability and Alrotold Chrracteristics," has been prepared by Mr. Fulton Ko Fesrs, a former greduate asslotent on our stafr. The papor is a sumnary of Mir. Fears? thesis that was proviously submitted and will bo presented at the Highway Research Board Annual Meoting in January, 1958 .

The paper 18 oubmitted for the rocord.

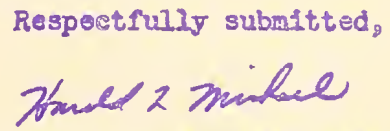

Harold Io Michael, Assigtant Director Joint Highway Resoarch Project

\section{HLM:hgb}

Attachanen

ce: A. Ko Branhara
Jo Ro Coopor
Wo Lo Dolch
Wo Ho Goetz
Jo To Hallett
E. Fo Havoy
G. A. Hawkins
Go Ao Loonards
Jo Fo KcLaughlin

R. D。 Kileg

R. E。 MIIs

B. H. Petty

Wloyd Poindexter

H. B. Scott

C. E。 Vogelgesang

J. Lo Waling

J. E。 Wilson

E. J. Yoder 
Digitized by the Internet Archive in 2011 with funding from

LYRASIS members and Sloan Foundation; Indiana Department of Transportation 
TECHNICAL PAPER

CORRELATION BETWEEN CONCRETE DURABILITY AND AIR-VOID CHARACTLRISTICS

\author{
by \\ Fulton K, Fears \\ Former Graduate Assistant \\ joint Highway Research Projeet \\ File: 5-8-17 \\ Project: $\quad C=36 \times 37 Q$
}

Purdue University

Lafayotte, Indiana

Decomber 18, 1957 
1

Fulton K. Fears, Assoclate Professor of Civ1l Englneering University of Oklahoma

\section{INTRODUCTION}

Numerous investigators have reported $(4,5,7,9,20,19,25)$ * laboratory studies showing incresses in durability and resistance to ocaling which result from entraining air in concrote mixes. Several of these studies ( $4 y$, 3 ) show that resietance to deterioration under repsated cycles of Eroezing and thawing of concrete made with poor aggregates is soinotimes greatly increased by air entrainment. Andrews" report (3) of the performance of concrete test roads In the northeastem states bullt with a wide range of variables shows a compartion of the ffeld perfomance of afrontrained conerete with adjacent sections of the ame construction but without alr satraln mont. The report shows that high rosistance to tho severo exposure of repeated cycles of freezing and thewing and salt action in ice renoval has been given to these concrete pavements over a period of ten to foure teen years by air entrainment, Jackson (10) and Connorman (9) report that the performance under service canditiona of experimental paving projests constructed with alroentrained portland coment pare110ls the results of the laboratory studies, Thus the superior performance in general of alruntrained concrete has been demonstrated in both the field and the laboratory

Reports of reseaxch on air entralment deal principally with factore which control the amount of air or with changes in properties of

Formerly Graduate Assistant, Jolnt Highway Research Project, Purdue University

Numbers in parentheses refer to the list of references at the end of the paper. 
the concrete rolated to changes in the gross amount of air. However, theoretical and practical considerations suggest that the properties of the air volds themselves are important factors Influencing the ability of concrete to withstend freozing and thawing conditions (11, 13,14, 15, 16)。

Considerable research on the effect of air entrainment on the duram bility of concrete beams as messured by resistance to deterloration under repeated cycles of freczing and thawhing has been performed in the laboratories of the Jolnt Highway Research Project at Purdue University. The atudies reported by Blackburn (5) and Bugg (7) show increases in the laboratory durability of alreentrained concrete made with limestone aggregates wich have poor to fair fleld service records over concrete made wh the same materials but without the inclusion of alr.

Subsequent studies of the effect of air entralnment on the durabIlity of concrete made with aggregates with poor to fair field perfor mance records have shown at times considerable differences in durability between beans from the same mix and between mixes contalning the same meterisis and which have the sane total air contant as determined by measurements on the fresh concrete. Hence, this study was initiated to determine which proporty of the entrained air is most significant in producling durable concrete and to what extent differences in durability can be explained by differences in the air $\rightarrow$ vold characteristics of the beams. The air-vold characteristics either measured or calculated were: (a) total alr content, (b) number of volds intersected per inch, (c) speciflc surface, (d) hypothotical number of volds per cublc inch, and (o) vold spacing factor, 


\section{Theors}

Entrained air appoars to oxfist in the form of cmall, disconnocted atr bubbles distributed throughout the concrete paste (20). The matural volds found in concrete made without an airsentraining agent vary cons olderably among different mixes but are generally larger than the bubbles produced by air entrainment (16). Thess natural volda rosult from the entrapping of air in the conerete $m i x$, In the aircentrained concrets the composite system of voids is a combination of the natural volds and antrained als bubbles. Warren (22) found that the average diamoter of the volds for a series of alrontrained mixes varied from 0.04 mill $=$ meters to 0.10 millimeters.

Powers and Helmuth (13, 25) oxplain the freozing of water in haro dened portland-cement paste in terms of two mechanksms: (a) the genera= tfon of hydraullc pressure as watox freezs in capillary cavitios, and (b) the growth of bodies of 1 ce in the caplilary cavities or air volds by diffusion of water from the gel pores. A brief rovlew of these two mechanlsms follows

Hardened portaland=cement paste is made up of extremely tiny spheres IIriked together to form the cohesive mass called cement gel. When the cement gel completely flils the space avallabs to it the porosity of the paste 18 about 25 percent. In most pastes the volume of the gel doss not equal the apparent volume. The unfllled space in the pasto occurs as cavities which are called caplllary pores. The gol pores aro the interstitial spaces among the massed spheres which ourround the carttes.

The gel pores are so small that water cannot freeze in them at ordinary temperatures, Thus, at these temperatures, the capillary 
pores or savities are the only places where Ice can exist within the boundaries of the paste However, the capillary pores are also so amall that the ice crystals wich they contain can exist only when the temperature is below the normal freezing point. Als volds such as those in air-entrained concrete are extrenely large compared with the caplliary pores and gel pores in the paste.

In a water-soaked paste the caplllary pores and the gel pores are full, or nearly full, of water. When tho water In a saturated capillary pore begins to change to 1 ce the volume of the water plue 1ce will exceed the original capacity of the cavity Th1s comes about because one cublc centineter of water occuples about 1,09 cubic centimeters of sparo after freezing. Therefore, during the time the water 19 changing to Ifs: the cavity must dilate or the excess water must be expelled from 1t. Although the coefflcient of parmesbility of the cement gel Is ex. tramely low there is the possibility that the excess water can escape from the capillary cavity during freazing, The growing 1 co body in the caplilary cavity may be considered as a sort of pump foreing water through the cement gel toward an alr-vold boundary. Such a pumping action Involves the generation of pressure. In general, during the process of Iseezing, hydraulic presgure will exist throughout the paste, and this pressure w111 be higher the farther the point in question is from the neareato alr-vold boundary where the pressure is relleved, By reducing the dis tance between alr volds to the point where the protected shells surm rounding air voids overlap, the generation of disruptive hydraulde pressure during the freezing of water in the capillaries can be provented

The generation of hydraulic presoure through the prevlously described mechanism does not account for all the phenomena that sccompany freezing 
Powers and Helmutb (15) suggest that part of the disruptive effect of freozing is caused by the tendency of microscopic bodies of ice to grow by difrusion of water from the gel pores to the capillary cavities, producing expansion. This may occur at any temperature below the tempera= turo at which the 1ce in a cavity was formed。

The functions of the entrained-air volds are (a) to limit the hydraulic pressure in the paste during the initial stages of freozing; and (b) to IImit or prevent the growth of microscopic bodies of Ice in the paste while the tempersture is below the normal freezing point, Powers (14) has derived a formuls from which can be calculated the theoretical maximum distanco from any point in the paste to an alr-paste interface which can occur without disruptive hydraulic pressure being genorated. For this roid spacing factor he has suggested an upper linft of 0.01 inches. This value may 2180 be considered satisfactory for the prevention of damage due to the growth of lce bodies.

\section{Develorment of the Linoar Traverse Technique}

The methods which have been used for the measurement of air in haro dened concrete have been based on the procectures followed by the geolow glsts in the measurement of winerals in rocks. Insoln and Rietz (12) reviowed the devolopment of the mensuration methods used by the geologists in an article in Economic Geology in 1913: They reported that the first mensuration mothod to make use of physical measurenents was the areal method of Delesse in 1848, Delosse applied a transparent sheet of paper of goldbeater"s skin to the polished or nearly plane surfece of a rock and traced upon it the outline of the various mineral grains. The sketch was then tinted so that the various minerals could be identified, and the 
ohoot pasted with soluble gura to a piece of tin follo The variously tinted surfaces with their adhering tin foll were noxt cut apart and grouped according to their colors, the papor washed away, the tin foil particles in each group weighed, and the percontages of the var1ous mineral compounds of the rock computed diroctly from thoso wolghts.

The linear menouxetion method was devised by Rosiwal (18) in 1898 for the messurement of the minerals in a rock. It consisted of measuring the Intercepted lengths of grains along a line or series of lines and calculating the percontage by volume by divlding the total diatance Into the sum of the intereepts for each component. Rostwal presented a proof by calculus to show that latercepts on lines are proportional to volumes. IIncoln and Rietz (16) presented an alternate geometrical proof.

Shand (19) developed a rocording micrometar which could be used to add the Intarcepts for a givon mineral 28 wall as to rake the measurem ments. This instrument was used with a microscops in the examination of thin sections of rock. Wentworth (23) tragrowed on the recording zictometer by doveloplng an eccossory stage whereby separate wicro= meters accumulatod intercepts for assigned minerals,

There have been soveral methods appliod to the doterwinetion of air volds in hardened concrete. Verbecl (20) reported a vieual method for deterwining the anount of air by planinetering camera Iuciala tracingr of polfshed sect1ons of concrete。 Warres (22) used a procedure marrby the alr volds exposed by a pollshed surface were fliled with a fluoreso cent matorial and photographed under ultra-violet Iight. Measurensnts were then made on the photographs to deterwine the alravold paranetero. 
Raxpord (17) observed thin sections of the cement paste and made the measurents with the Wentworth rocording micrometer.

Brown and Plerson (6) applied the principle of the Wentworth rocording mierameter to the construction of a linear traverse integrator of spocial design with two recording motions, one for the air volds and one for the solids. This instrument is used in conjunction with a binocular microscope, generally working at a magnifleation of 30 to 40 diamsters。 The use of this apparatus permits the observation of surfaces large enough to afford true representation of aggregete and 2 loo of the occan 8lonal large air vold that occurs in practically all concretes. The binocular microscope greatly facllitetes the perception of air volde. The amount of work involved in the preparatfon of the surface of the specimen is less than that required by the other methods. Therefor $\theta_{0}$ equipment and procedures similar to those recomended by Brown and Plerson were used in this study. 
EGUIPIENT AND TECHNICUES

The appuratus for tho moasurement of the alr content and the number of volds per inch 18 shown in Figure 1. The three principal parts which make up the Iinear traverse integrator are the grooved base plate (A). the lower front and back $\operatorname{rafls}$ (B) to which the middle plate (C) Is attached, and the upper Iront and back ralls (D) carry the top plate (E) on which the conerete speciemen (F) is placed. The lower rails ride in two grooves in tho base plate. The front groove (G) ie rectangular in shape while the back groove (H) lo Voshaped to aline and guide the ralle,

The main lead screw (I) 18 attached to the base plate by two bearIng blocks (J): At the right and lo a revolution counter (K) which is used to record the distence traveled by the lower rells and middlo plate which represents the distance across the solid constituents of the concrete Power is supplied elther manually by rotating a knurled wheel (A) or by an electric motor (M) at the left of the screw. One revolution of the main lead screw produces a tenth of an inch of translation.

The middle plate, to whlch the lower ra1lo are attached, carries the top plate lead screw (N), a second revolution counter $(0)$, and a hand wheel $(P)$ for controlling the movement of the top plate relative to the middle plate. The Becond revolution counter 18 used to record the distance across the alr volds in the concrete. One revolution of the top plate lead scrow produces a hundredth of an Inch movement of the top plate. A ratchet counter (C) Is used to tally the number of air voids encounterod in a traverse,

A binocular microscope (R) 18 used with $3 \mathrm{X}$ objectlve lenses and 15X eyopieces to produce a magniflcatior of 45 dianeters, Crosshairs 


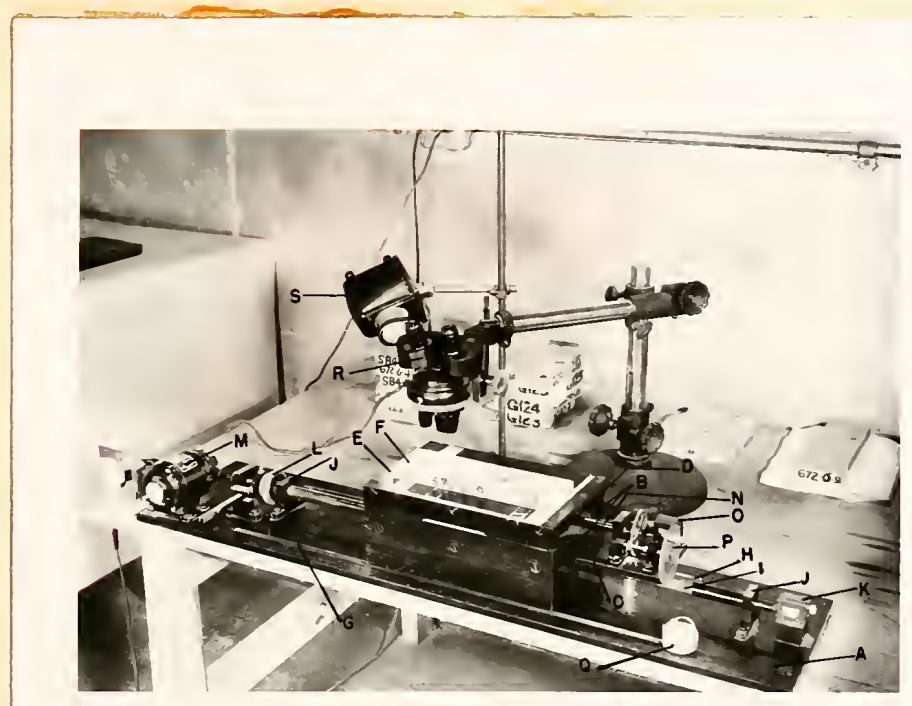


Interaecting at 90 degrees are mounted in one eyeplece so that the groshalrs make an angle of 45 dogrees with a line in the direction of movament of the Intersection. A spotlight-type mioroscope lamp(S) Is positioned to throw a beam of light os the specimen at a low angle so that the shadows facliltate the recognition of the alr volds.

In using the IInear traverse integrator the concrete specimen is moved to the right or left as desired by means of the main lead serew unt11. through the microscope, the observer sees an air vold coming into the fleld of view. He stops the motion with the msin lead screw when the intersection of the crosshairs is at the edge of the als rold. He then uses the hand wheel on the middle plate to move the intersection of the crosahairs to the opposite edge of the air vold and one. vold 18 tallied on the ratchet counter, Motion is resuned with the main lead screw until the interesection reaches another ais vold and the proeess is repeated, A mall scale is used to messure the distance from the edge of the top plate to the concrete specimen in order to obtain un1formly spaced traverses.

The distance in Inches across the solid components is found by dividing by ten the number of revolution recorded on the revolution counter at the right end of the main lead screw. The distance agrose the air volds in inches is obtained by dividing by one hundred the readen Ing on the second revolution counter. The sum of the two distances gives the total length of the traverse. The distance acrose the alr rolds divided by the total length of the traverse is an estimate of the total sir content of the concrste. The number of volds per inch is computed by dividing the total number of volds by the total length of the traverse. 
In this study, slabs approximately one inch thick were cut from concrote beam specimens by means of a masony saw, A wetucutting steel bond diamond blade was used on the saw. The size of the beams from which the olabs wore cut was $3 \times 4 \times 16$ inches. First, approximately three Inches were removed from each ond of the beam. Then longltudinal cuts were made through the threesinch dimension to produce a one inch 8 ab from the center portion of the beam. The sawed surfeces, spproximately $3 \times 10$ inches, on each side of the slab were used for determining the alrvold characteriatics of the beam. Modiflcations in sawing were necessary depending on the degree of deterioration of the individual beam.

The initial polishing of each surface was done on hard plate glass 24 Inches square using Grade No, 180 aluminum oxide powder. Water was used as a lubrlcating and dispersing medium during grinding and for washing the polished surface. After twenty minutes of polishing, the surface was thoroughly wsshed using a nozzle to produce a pressure to ald in removing the grinding powders from the volds. The washing procedure wes repeated after another twenty minutes of polishing. The sbove procedure was then repeated using Grade No. 240 sluminum oxide powder. Thus, a total of eighty minutes was spent in polishing on each surface with two grades of grinding powders.

The final polishing was done with a portable belt sander, A wooden fig was used for holding the slabs in plece while the pollshing was bolng done. Silicon cerbide abrasive belts Grit No. 240 were used. One belt was used to pod1sh two surfaces alternating between the two surfaces so that a totel of ten minutes of polishing was done on each surface,

This procedure produced polished surfaces on which the volds were 
sharply defined and measurements on a given treverse could be repsated with practically the samo result for the $82 x$ content and the number of volds per inch.

\section{Studies of Position and Length of Traverse}

The Rosiwal method of determining the percentage by volume of the constituents of a solid requires that a random line be passed through the solid. This princlple is applied to a sample of concrote by first exposing a random gection and then maning a random traverse line in the plane of the section. In the actual application to a given beam the four surfaces of the beam are consldersd to have bean randomly selected with respect to the concrete mix from which the beam was made。

In order to determine the effect, if any, of the position of the traverse within the beam an Investigation of the variability of the als content and number of volds per lnch within the beam was made. Also, the effect of the length of traverse on the reliablisty of the measure. mests was gtudied. For this investigation two beams from a concrete mix containing a durable coarse aggregato were selected for examination, Each of these beams had withstood 800 cycles of freezing and thawlng without any loss in dynamic modulus of elasticity.

The original beam dimensions were $3 \times 4 \times 16$ inches. Three inches were removed from ach end of the beans by sawing. Then three cuts were made longitudinally through the three-inch dimension so that four alabs approximately $3 / 4$ - Inch thick were produced from each beam. Three gurfaces Prom oach been wore polished for oxanination by the IInear tram verse integrator, The throe surfaces selected for exanination were those which could be considered to represent three rertical planes spaced tiffough the beam at approximately oneoinch intervals. These planes are 
designated $2^{\circ}, 2^{\circ}$, and $3^{\circ}$ in Figure 2.

To study the effoct of using traverses of different longths, deter. minstions of the air content were made using traverses of four different lengths. Four equally spaced traverses were measured on each pollshed surface. Thus the twelve traverses in each beam could bo considered to fall within three vertical or four horizontal planes as shown in Figure 2. An estimate of the air content of each beam was made using the flrst four inches of esch treverse starting at the right edge and moving the beam to the righto Estimates were then made using the first six Inches of each traverse. Then the flrgt eight inches of each traverse were used. Finally all ten inches of each traverse were exanined. The estimates for each traverse are given in Table 1.

\section{Statiatical Analysis}

The statistical procodure known as the "analysis of variance" (8) for testing for algnificant differences among two or more means was followed to determine if the measured air cantent is Influenced by the position of the traverses with respect to horizontal or vertical planes within the beam. The analysis is based on the fact that if means of subgroups are greatly different, the variance of the group means is much larger then the veriances within separate groups. In this particular study the subgroups are horizontal or vextical planes,

The results of this type of analysis are usually presented in an analysis of variance table (see Tables 2 and 3). The values shown in the columns headed "Mean Square" are measures of the variability among the data which may be attributed to the factors 1 isted In the colum headed "Source of Variation." The number of degrees of freedom is one less 


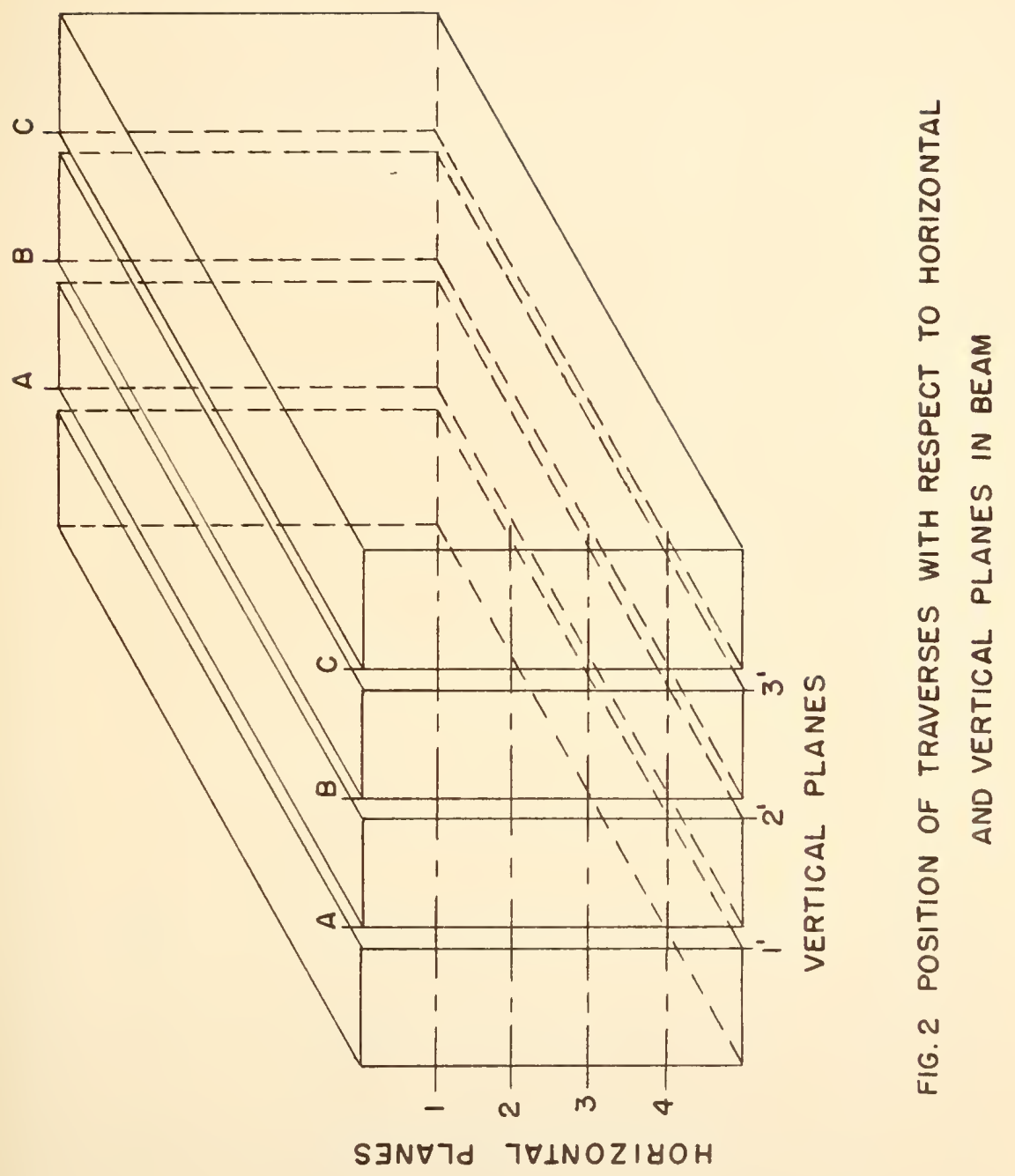




\section{TAB}

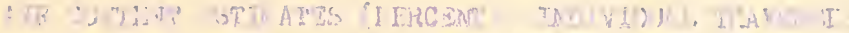

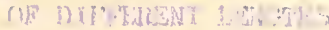
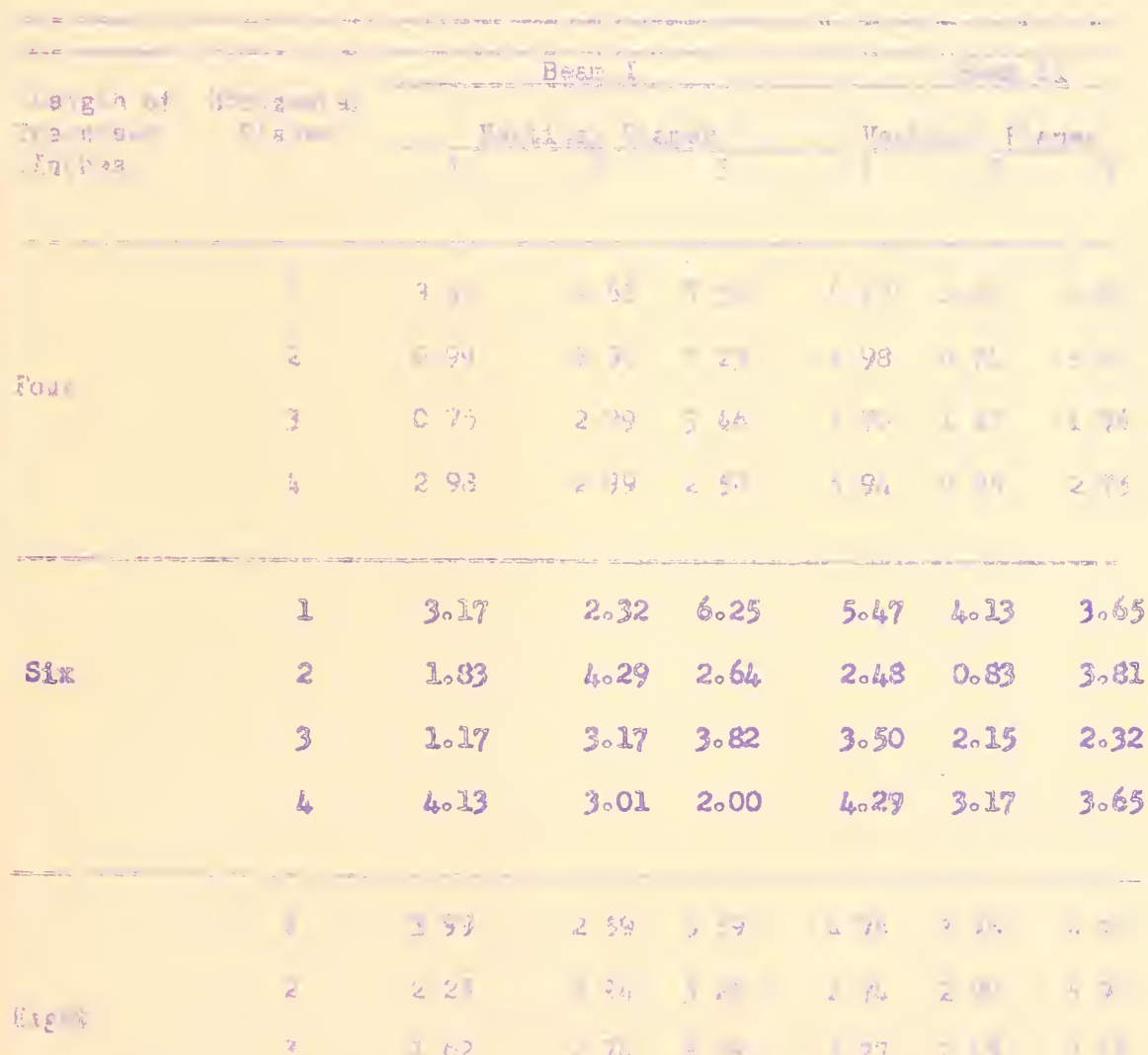

m.r. 
TABIE 2

ANALYSIS OF VARTANCLDodTR CONTEIT (PERCENT)

HOSIZONTAL PLANES

Length of

Traverses

(Inches)
Source of

Variation
Degrees of Mean \&

Suan of Squarea

Freedom
Berms

P1. In Bn。

Pr. In P2

Total

Four
0.2135

20.5382

Six

P2. In Bn。

Pro in P1.

Total

Beases

0.7597

18.8063

44.2423

63.7083

25.7296
1

6

16

23
10.75970 .24

63.13442 .14

2.7589

0.11350 .06

6

$1.7564 \quad 1.09$

16

1.6091

EIght

23

Beares

0.8893

1

$0.8893 \quad 0.53$

P1. In Bra。 9.9966

6

$1.6661 \quad 1.43$

Tro in P1. $\quad 18.6942$

16

1.1684

Total

29.5801

23

1

$\begin{array}{cccccc}\text { Beams } & 0.0084 & 1 & 0.0084 & 0.01 \\ \text { PI. In Bm. } & 6.5401 & 6 & 1.0900 & 0.83 \\ & \text { Tr. In PI. } & 21.0441 & 16 & 1.3153 \\ & \text { Total } & 27.5926 & 23 & \end{array}$

F $(4,18)=2.93$

0.95

$F_{0.95}(6,16)=2.74$ 
TABLE 3

ANALYSIS OF VARTANCE- AIR CONIENT (PERCENT) VERTICAL PLANES

Length of Traverses (Inches)

Source of

Varlation Sum of Squares
Degrees of Meas F Freedom Square Ratio

\begin{tabular}{llllll}
\hline & Beams & 0.7597 & 1 & 0.7597 & 0.24 \\
Four & P1. In Bm。 & 21.9916 & 4 & 5.4979 & 2.42 \\
& Tro in P1。 & 40.9570 & 18 & $2.2754-$ & \\
& Total & 63.7083 & 23 &
\end{tabular}

Six

0.1335

P1。 In Bin。

6.2004

Tr. In P1。 30.0674

36,3813

Total

2

0.11350 .07

4

$1.550 \%$

0.93

18

1.6704

23

\section{Beams}

0,8893

1

0.8893

0.73

EIght

P1. in Bno 4.8686

Tr. In P1。 23.8222

4

1.2172

0,92

Total

29.5801

28

1.3235

23

\section{Beams}

P1, In Bus,

Ten
Tr。 in P1.

Total
0.0084

7.4788

20. 1054

27.5926
$10,0084 \quad 0,00$

$\begin{array}{lll}4 & 1.8697 \quad 1.67\end{array}$

1.2170

23 
tha the number of ralues drvolyad in the compatation af the sum of squarso. The mean square is obtained by dividing the sem of aquares by the corresponding degreas of freedon for the given factor The $F$ ratio is used to test for slgnificanco. It is foried in this case by taking the mean squara found on the line whose fifet is being tested and dividing by the mean square of the rext lower subgroup in the samp= ling procedure If tisicis retio is less them the F ratio at some chosen levol of signiflcance based on the Fishsz variance ratio probabil1ty Law then it may be concluded that the particuiar iactor boing tosted is not significant. Tn this case, for Instance, raference to Table 2 show thet the neasured a1r content is indopendent of the particular horlzontal planes fror which tlio traverses waro selected.

The Fatios for a siznificance Ievel of 5 parcent axe F $(4,18)=293$ for vortices planes and $F \quad(10,16)=2.74$ for hortantal 0.95 planes. Inspoction c5 Tables 2 and 3 does not show any F ratio which 18 significant at the 5 porcent significance level Similar iegults wore obtained in the gtudy of the varieblizty of the nusabs of vadds Intersented per snch. Hence, it may be concluded that gif content and number of voids per trach may be determined without regard to the hor. zontah or portical. planas within wich the traverses may fall

A 90 percent confldence leval for determining the alr content of an Individual beam within 40.5 percert of the true a1 $\bar{L}^{\prime}$ ccutort wes solocted. Table 4 pressnts the regugts of the stuay of the offect of the length of the individual travarse on the confidence lindts for the mean ais content. The standard error: of the nean is shown to decrease as the length of the traverse $1 \mathrm{~s}$ inereased whth the total number of traverses remaining the same Shen the standard exros of the mean 18 computed on the basis of a total of 120 inchez of traverses, ft is approxinately 0.3 for tra- 


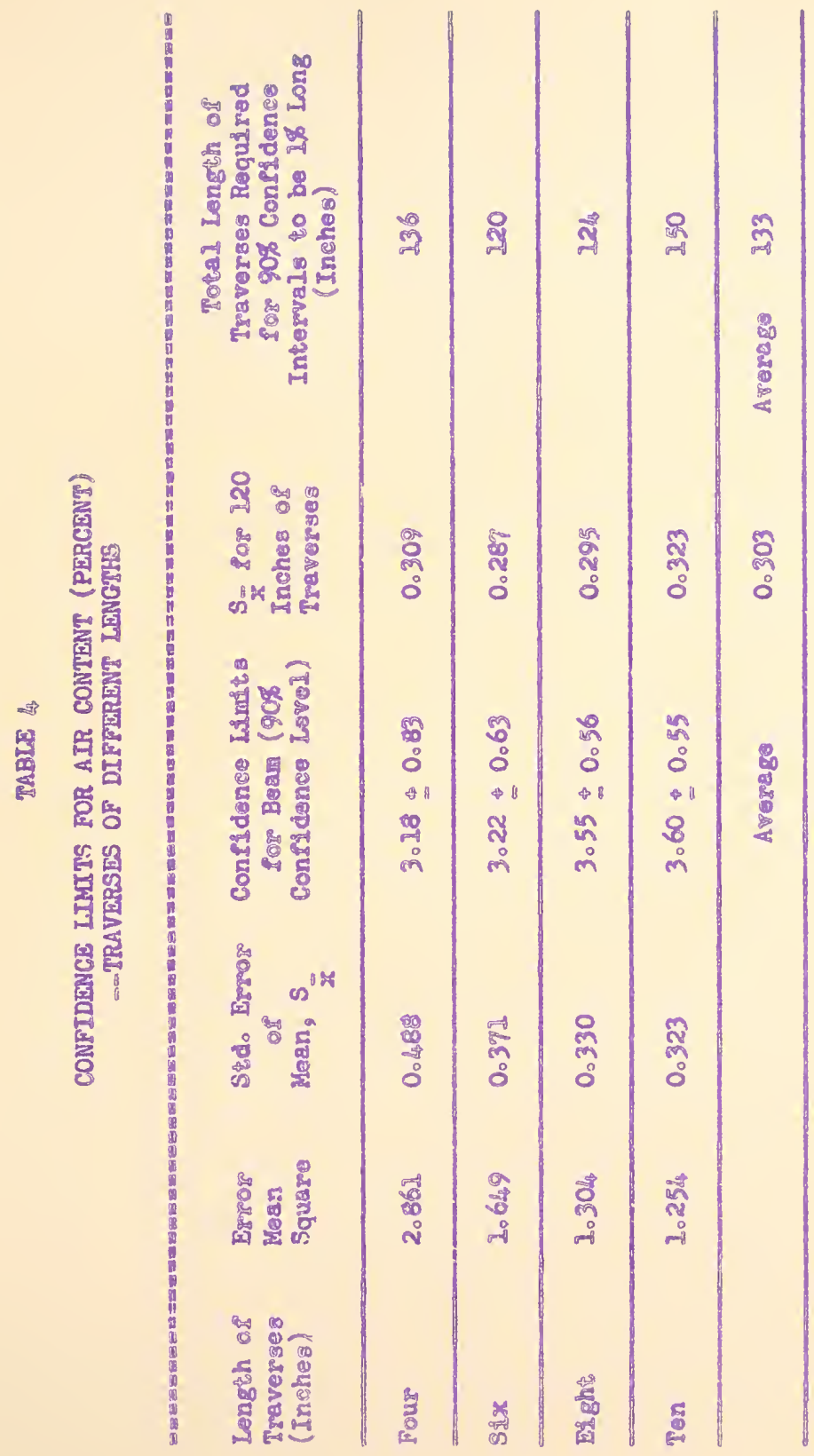


verses of all lengths. Very similar results were obtained for the number of volds per inch. Therefore, the totgl length of the traverses determines the conflience Ilmits for the air content and number of voids per inch rather than the length of an individual traverse,

The meacurement of the air content and number of volds per inch of an individual beam may be considered as one long traverse。 Table 4 shows that the total length of this traverse should be approxinately 135 inches to give the air content of a beam of the type studied within $\$ 0.5$ percent of the true air content. In order to allow for some increase in variabllity when examining concrete from other mixes, one hundred inches of traverses on each of two surfaces (200 inches total) were selected as standard procedure for the measurements.

To provide a check on the selection of 200 inches as the total length of the traverses to be measured for a given beam, three additional gurfaces (Planes $A_{3}, B_{0}$ and $C_{0}$ Figure 2) from each bean were poliahed and ten traverses, each ten inches in length, were nessured on each surface, The planes within each beam were combined in peirs and the confidence Iindts computed as given in Table 5. The atr content and the number of volds per inch are shown to be within the limits of 0.5 percent and $\$ 0.5$ void per inch, respectively. Also 1 t may be noted that when any two planes are combined the difference from any other combination for the given beam is small,

In order that some camparison might be made between the measure ments reported in this study and those made in other laboratories, six concrete specimens wers obtained from the Portland Cement Assoclation Laboratory, The results of the messurements made on these specinens are reported in Table 6 . One hundred inches of traverses were run on 
TARLE 5

CONFIDENCE LIMITS FOR AIR CONTENT (PERCENT) AND NUMBER OF VOIDS PER INCH - INDIVIDUAL BEAMS $=$ TWO HUNDRED INCHES OF TRAVERSES ON TWO PLANES

\begin{tabular}{|c|c|c|c|}
\hline Beara & $\begin{array}{l}\text { Two Planes } \\
\text { Combined }\end{array}$ & 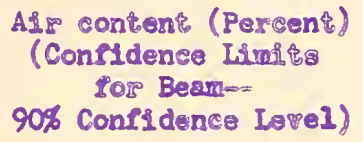 & $\begin{array}{l}\text { Number of Volds per Inch } \\
\text { (Confidence IImsis } \\
\text { Ior Beaw } \\
90 \% \text { Confldence Level) }\end{array}$ \\
\hline \multirow{3}{*}{$I$} & $A$ and $B$ & $3.41 \pm 0.39$ & $4034=0.35$ \\
\hline & $A$ and $C$ & $3046 \div 0.42$ & $4046 \neq 0.40$ \\
\hline & $B$ and $C$ & $3.65 \div 0.42$ & $4.47 \pm 0.38$ \\
\hline \multirow{3}{*}{ II } & $A$ and $B$ & $4011=0.42$ & $5074=0.25$ \\
\hline & $A$ and $C$ & $3.93 \pm 0.36$ & $5058 \div 0.26$ \\
\hline & $B$ and $C$ & $3.92+0.36$ & $5.247=0.30$ \\
\hline
\end{tabular}


TABLE 6

CONFIDENCE LIMISS FOR AIR CONTENT (PERGEDT) AND NUREER OF VOIDS

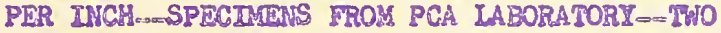
HUNDRED INUCHES OF IRAVIBRSES ON THO PLANES

\begin{tabular}{|c|c|c|c|}
\hline Specน์men & 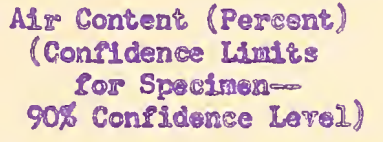 & $\begin{array}{l}\text { PCA Values } \\
\text { for } \\
\text { Airs Content } \\
\text { (Parcent) }\end{array}$ & 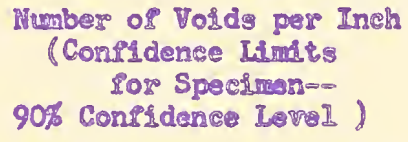 \\
\hline है & $3.53 \div 0.65$ & 3.6 & $1.26 \approx 0.17$ \\
\hline 2 & $1.52 \neq 0.35$ & 1.6 & $0.69 \neq 0.12$ \\
\hline$S=8$ & $1.09 \& 0.24$ & $\mathbb{B} 0$ & $0.67 \neq 0.09$ \\
\hline $\mathrm{U}-15$ & $4048 \pm 0.51$ & 408 & $6.80 \div 0.51$ \\
\hline 83 & $2014 \$ 0.42$ & 2.3 & $1.13 \notin 0.23$ \\
\hline $30-A$ & $8.43 \neq 0.67$ & 8.0 & $12091 \& 1004$ \\
\hline
\end{tabular}


each of two surfaces of each spectmen The results substantlate tho procedure developed in this study. $A 180_{2}$ the air content measuremente check very closely with those obtained in the Portiand Cenent Aseoclation Laboratory, 


\section{MATERIALS}

Concrete beame which were fabricated for use in another investiga tIon conducted in the concrete laboratory of the Jolnt Highway Research Project were selected for examination in this study. These beams were chosen because of unexplained differences in durability botween beams containing the same materials and the same total air content as determined by measurements on the fresh concrete. It appeared that exam1nation of these beams would provide Information of particular value regarding the previously stated objective of determining which property of the entralned air 18 most signiflcant in producing durablo concrete.

A1l beams used in this study were made with cmashed stone coarse aggregates. Data on these aggregates are presented in Table 7. The six cosre aggregates from the sources in the Kokomo limsstone formation have poor durability records, The source from the Liston Creek forma tion has a good fleld performance record.

The fine aggregate used in 811 mixes was obtained from a river ter race deposit of glacial orighn. This fine aggregate has been used in the Joint Highway Research Project conerete laboratory for years as a standard matelolal and is considered to be a dursble material in laboratory freeze-thaw wathering. The bulk satursted surfece dry specific gravity of the flne aggregate was 2.65 and the Pineness modulus for the gradation wa's 3,10. The absorption was 1.65 percent by welght.

Type I portland cament fror a single clinker batch was used in all mixes. Darax and neutrallzed vinsol resin solution were used as airo ontraining agents. 


\begin{tabular}{|c|c|c|c|c|c|c|c|}
\hline 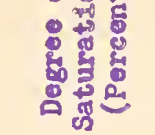 & 2 & 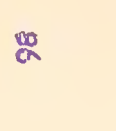 & & 8 & 离 & 8 & \\
\hline 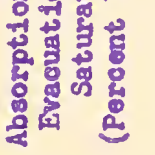 & a & $\stackrel{0}{0}$ & ๙̊ & $\begin{array}{l}\infty \\
\infty \\
\text { ñ }\end{array}$ & ले & $\begin{array}{l}\text { مే } \\
\text { nే }\end{array}$ & \\
\hline & 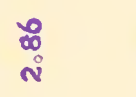 & 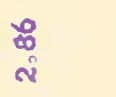 & & $\begin{array}{l}\stackrel{\circ}{\infty} \\
\stackrel{\sim}{*}\end{array}$ & $\underset{\substack { \infty \\
\begin{subarray}{c}{\infty \\
\sim{ \infty \\
\begin{subarray} { c } { \infty \\
\sim } }\end{subarray}}{ }$ & 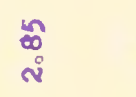 & 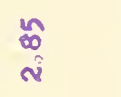 \\
\hline 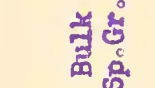 & $\underset{\substack{\infty \\
\text { ஸे }}}{ }$ & חָ & $\begin{array}{l}i n \\
\hat{i n}\end{array}$ & & & בּُ & \\
\hline 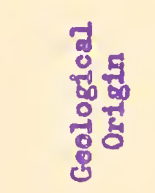 & 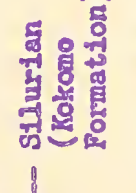 & 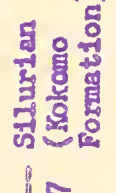 & 弯递 & 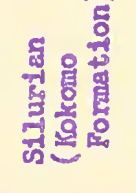 & 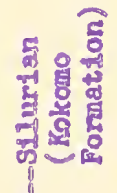 & 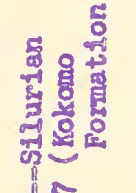 & 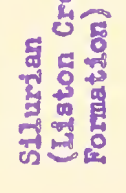 \\
\hline 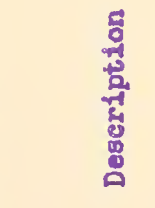 & 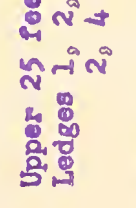 & 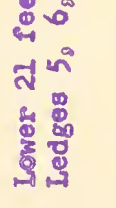 & 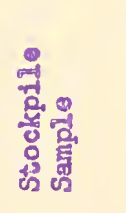 & 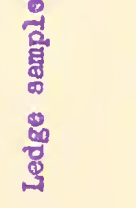 & 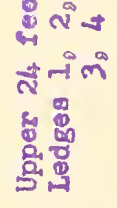 & 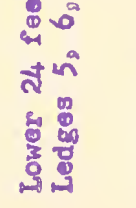 & 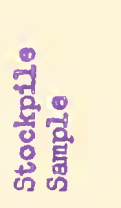 \\
\hline 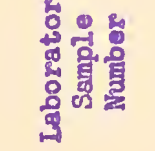 & 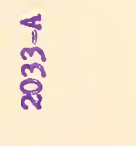 & 罢 & 品 & 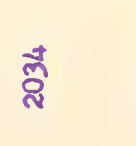 & 謫 & 哭 & 商 \\
\hline 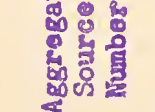 & 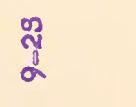 & జֶ & $\begin{array}{l}y_{2} \\
y_{\alpha}\end{array}$ & $\frac{2}{2}$ & 足 & นึ & $\underset{7}{\overrightarrow{1}}$ \\
\hline & $\&$ & $x^{2}$ & $\&^{m}$ & $4^{+}$ & $e^{n}$ & $4^{\circ}$ & $q^{2}$ \\
\hline
\end{tabular}




\section{Conerate Mxes}

All coarss aggrogates were racuun baturated befor being incorpor ated in concrete mixes dealgned for a water-cement rat10 of 46 by welght, a comont factor of six hags per cuble gard, and a sluap of threo to four inches, The aaxinim Bizo of aggregate was one inch. The alm rontent of the fresh concrete was measured gravinetrically according to

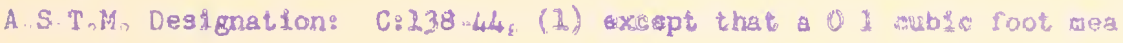

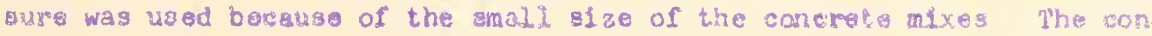
quet used for making the air content detormination way discarded Three conkrete beans, $3 \times 4 \times 16$ inches were made from each mix Curing

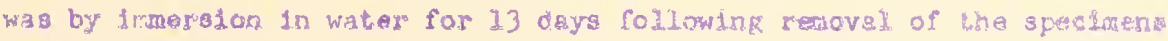
from molds one iay aftur casthing 


\section{MEASUREMENT OF DURABUUITI}

The relative durablilty of the beams was determined from their resistance to doterioration when subjected to repeated cycles of freozing and thawing. Automatio equipenent was used with the freezing and thawing cycles corregponding to AnS,T.M dogigration C291-52T (1) rapid freezing in air and thawing in water. Approxiliately seven eycleg per day were obtained.

Perlodic determinations of the dynamic modulus of elasticity wero made to measure the amount of doterioration. In most cases freozing and thawing was contirued until a decresse is dymanic $E$ to 50 percent of the orlginal value occurred or until 800 cycles of freezing and thawing were complebed

The seven coarse aggregates described in Table 7 were represented by 19 mixes: The number of mixes ueing each coarse aggrogate varied Reforr.ing to the aggregate designations in Table 7, $A_{1}$ was used in two mixes, $A_{2}$ in three $\mathrm{mlxes}_{8} \mathrm{~A}_{3}$ in two mixes, $\mathrm{A}_{4}$ in three mixes, $A_{5}$ In three mixes, $A_{6}$ in five mixes, and $A_{7}$ in one mix. For use in atudying the air-vold characteristica two beans were selected from each mix-methe most durable and the least durable, Thus, a total of 38 beams from the 19 mixes were studied

A durability factor was used to express the durability of each beam selected for measurement of the air-vold characteristics. This factor was computed following the procedure suggested by Stanton "alker (21). It may be deflned as the area under the curve (dynandc $\Sigma$ as a percent of the orlginal E plotted against cycles of freezing and thawing) to the Ieft of the 200th cycle and above the 50 percent dymamic E Iine expressed as a percentage of the total area to the left of the 200 th 
cyele and above the 50 percent dynamic E Iine, Table 8 gives the durability factors for the 38 beams which were selected for the measure ment of the air-void characteristics. 


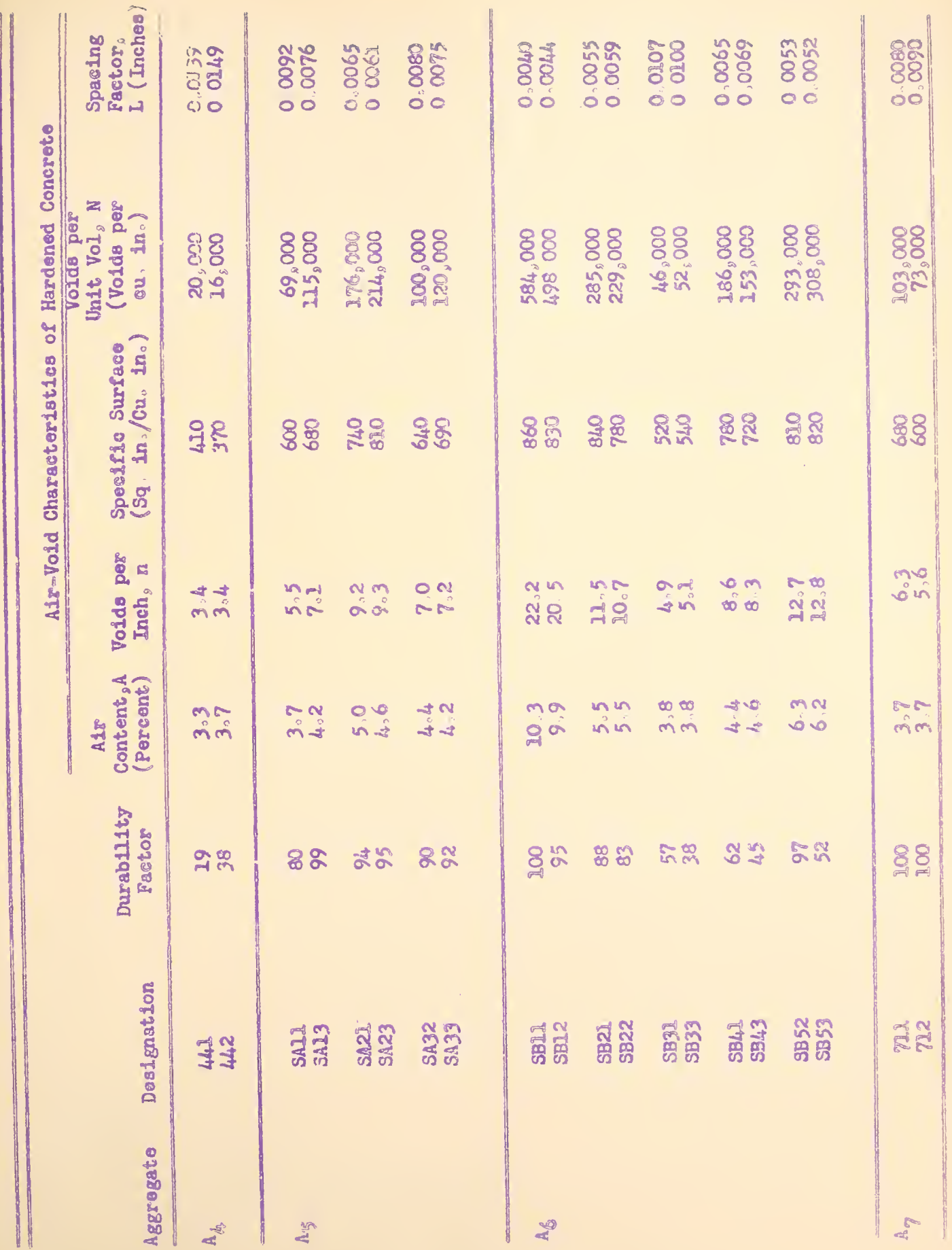


The air - rotd characteristics which were investigated for orrela. tion with durabijity were:

$$
\begin{aligned}
& A=\text { air content, total volume of volds per un: } t \\
& \text { volume of concrete, percent? } \\
& \mathrm{n}=\text { mumber of yoLde intersected per unit lengt } 1 \text { of } \\
& \text { traverse, voids per inch } \\
& \text { Me = the speaific surface of the aif volds, the aurface } \\
& \text { area of the voids per unit volume of } 21 r_{9} \text { square } \\
& \text { Inches par cubic inch, } \\
& \mathbb{N}=\text { number of hypothetical spheres having radiu? } r_{h} \\
& \text { that would eqeal the actur.l. air content of the } \\
& \text { conerete, volds per cubic juch, and } \\
& t=\text { spacing factor, distance from vold boundarg to } \\
& \text { outer boundary of sphere of influence, fnches }
\end{aligned}
$$

Two of the characteristics, $A$ and $n_{\text {; }}$ were measured directly 1 ith the Ifnear traverse integrator, The renaining three were computed fron these two measurements with the past content being introduced in th computation of the epreing factor

The equations that were used for the computations of $\alpha, N_{i}$ an $I$ Were presented along whth their devaloprent in the papex "The Air Priquire= men? of Frastorevistant Conerete" by T。 Co Powers (14) and a discussion of the same paper by T。F。 Willis $(24)$ :

I. F., W3IIa (24) showed that regardless of the size distribution of the voids the true speciflc eurface of the volds is given by the equation: $o f=\frac{4 n}{A}$.

(Eq, I)

$N$ and I are obtained by assuming that the voids are equal-a1ze 
Epheros vith each sphore having the same syorific surface as the measured Bpecific surface, Powers $\left(u_{t}\right)$ and Willis (24) Bhow that the radius If of thife hypothotical sphare is aguas to $\frac{3}{\sigma}$ or $\frac{3}{4} 1$ whare:

$1=$ tho asitis mean of the measured chord intercept $\$$

The hypotistical number of spireses, $N$, may be computed from the foldow lag formula:

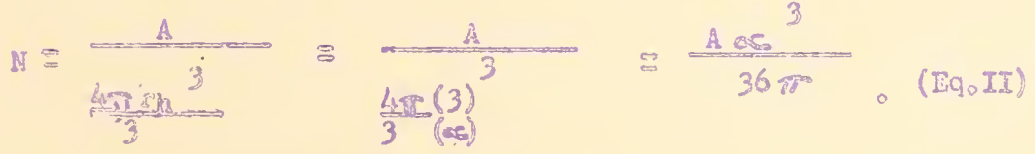

Thus the computation of $N$ and $I$ is based cra a hyothotical system of und forn-Bized spheres having the sme troture of air por unit volume of con crete and the same spseifle surface as the system of raycon sized yotels for which $A$ and $n$ are msasured.

To compute the vold spacing factor for tho hypothotical wold systerng each sphere is considered to be at the conter of a cube whth the sum of the volumes of 2.11 such cubes and the enclosed spheres equaling the combined air and pasto content of the concrete. The "sphere of influence" of egch vold is the redius of the sphare circumscribing the hypothetical cube, The spheres w11 overlap except at the corners of the cubes: The radius of the sphere of intuense 18 equel to onemalf the diagonal of the cube,

The volume of the single hypothetical cube is $\frac{p \text { if } A}{N}$ whore $p=$ paste content; sum of volumes of water and canent per undt volume of conerete Hence, the length of one edge of the hypothetscal cube is $\left(\frac{(p+A)}{(N)}\right)^{1 / 3}$. And:

$$
x_{m}=\frac{\sqrt{3}}{2}\left(\frac{D A}{N}\right)^{1 / 3}
$$


where $\mathbb{I}_{\mathrm{m}}=$ radius of circumscribed sphere, the "sphere of influence." The spacing factor $L$ iss equal to the difference boiween the radius of the ephere of influence $r_{m}$ and the radius of the sphere $r_{h}$ : that 18 $L=r_{m}=r_{h}$ (Eq, IV)

Values of $A_{v} n_{0} e_{2} N_{2}$ and $L$ for the 38 beams examined in this study are tabulated in Table 8 , 
In this study the durability of a given boan was affected by a number of variables in addition to the air-vold characteristica. In particulary the coarse aggregate alone could be expected to produce considerable differences in durability among the beams, since $s$ ix of the coarse aggregates were from sources with poor durablilty records. For a single concrete mix there is a given number of deleterious particles, and there are an infinite number of combinations in which these particles may be distributed in beams made from the $\mathrm{mix}$. Thus, even within a mix, large varlations in durability could exist as a result of differences in the combinations of deleterious particles in tho beams, Howover, since the effect of entrained air on the durability may be different when different aggregates aro used, it 18 belleved that by introducing the coarde aggregate as a variable the results of the study have a wider application, Other variables such as efflelency of vacuum saturation atmospherie temperature, skill of labor, and location of beams within the freazer could have an offect on the durablilty.

Hence, the beams examined in this study were rogarded as a sample randomiy selected from a universe of beams in which variables other than the entrainsd air existo. In order to determine the relative inportance of the five air..vold charagterietics in producing durabie concrete, the correlation tecinique was used to study the relationship betweon dur abllity and each afrovold characterist1c, Because of the coarge aggre= gate and other variables, extremely high corrolation coefficients would not be expected. 


\section{Linear Correlation - Ind1 yddual Bearn}

Firet, tho beams were considered as a sample from a population of beams without regard to their individus comatuents or fabrigation. The seatter diagran in which the durabilsty factor is plotted againgt air content is ghown in Figure 3. The scatter diagrams ualng the other alrovold characteristice are presented in Figures 4 through 70

Althcegh it is possible that some curve other than a stroight ing would give a higher correlation between durabilfty and a given alr-vold characteristic, it is belleved that for the purpose of this study a sitralght Ine fltted by the leasto Bquares method is Batisfactory. The result of the computations for slopes ${ }_{8}$ correlation coffledents $s_{2}$ and regression lines are surmarizad los Table 9. The theralue for testing the

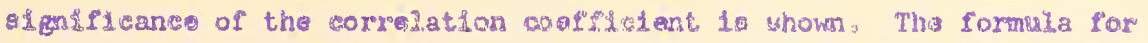
t. was taken from page 88 of Statistical Theory Ir Researeh by Anderson and Bancroft (2).. the slgnificance of the obserwed for ph-2 degroes of fredom fo Indicated in the table as well as the perceatage of the waxiation in durability which to explained by the regression line. The regression IInes have been plotted on the scatter diagrams

Because of the laxge differences in durablitty which could be Introduced by the coarse aggregate and other vartables thase ragression Ines should not be used to predict the durability factor for a given value of an alr-vold characteristic. They should be regarded as in.. dicating the trend in the change in durablifty factor with changes in an air woid characteristic. 


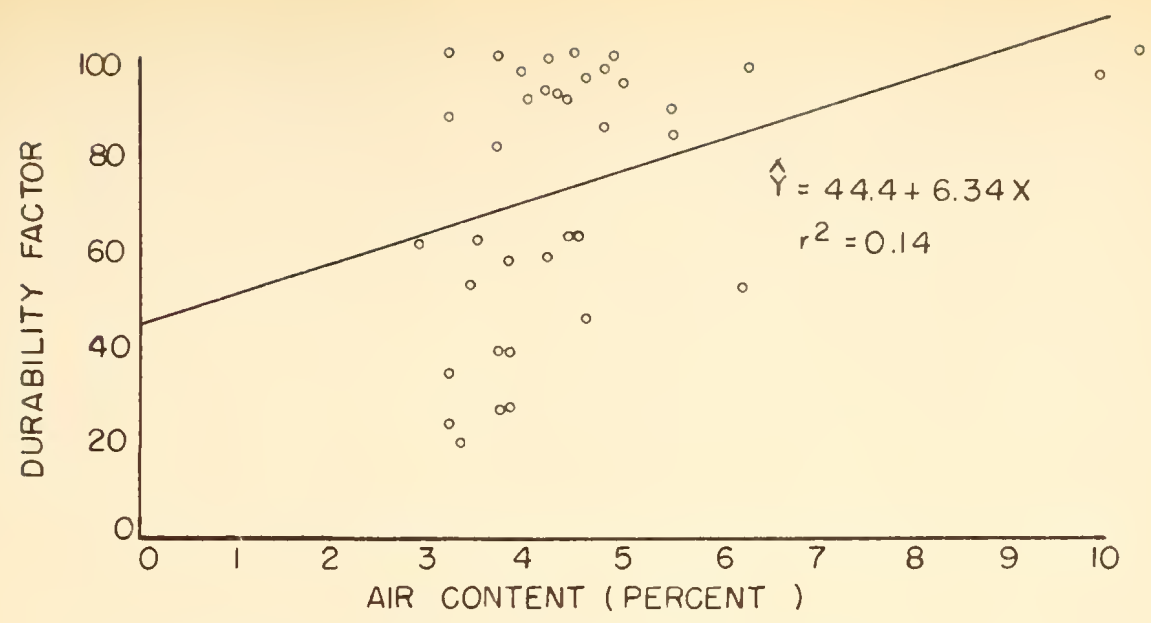

FIG. 3 DURABILITY FACTOR VERSUS AIR CONTENT.

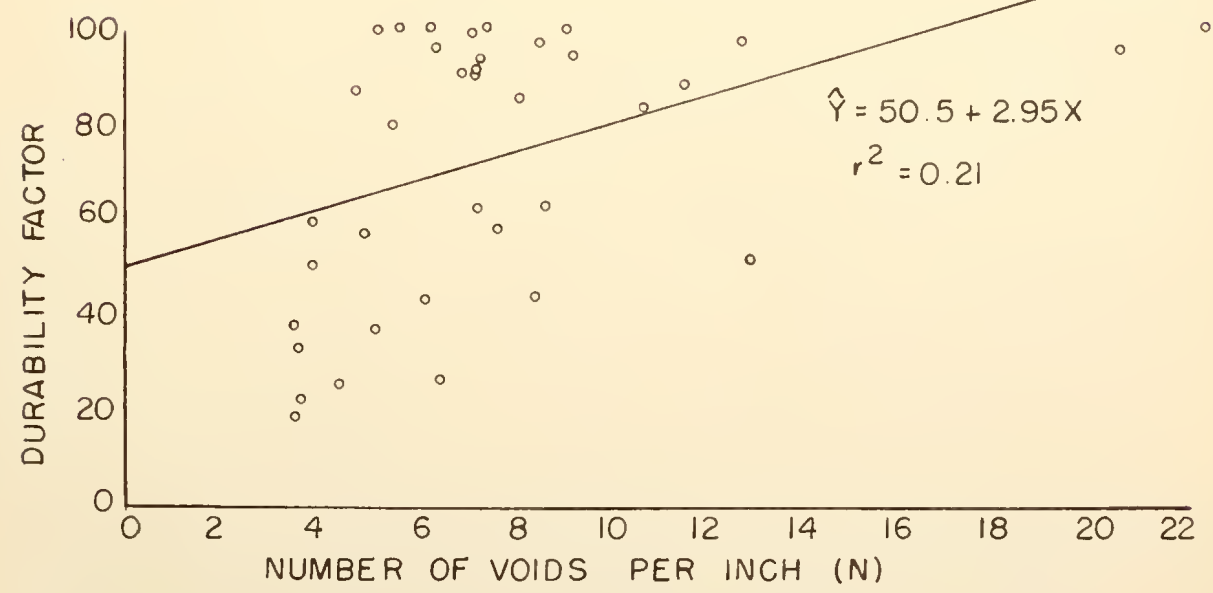

FIG. 4 DURABILITY FACTOR VERSUS NUMBER OF VOIDS PER INCH. 


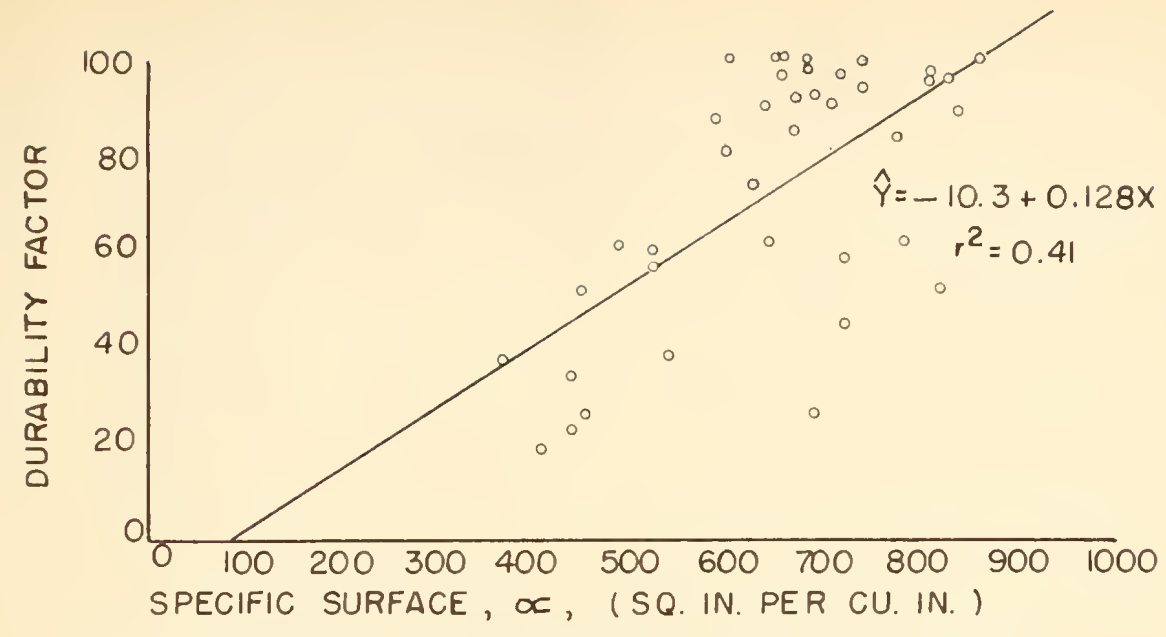

FIG. 5 DURABILITY FACTOR VERSUS SPECIFIC SURFACE

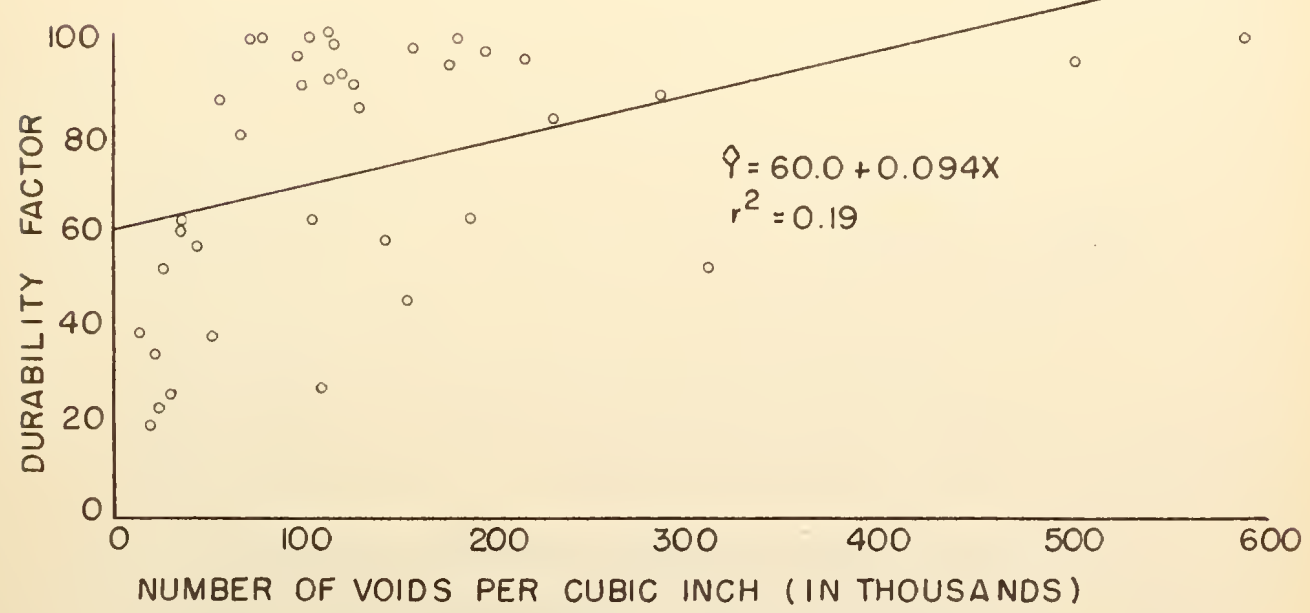

FIG. 6 DURABILITY FACTOR VERSUS NO. OF VOIDS PER CUBIC INCH. 

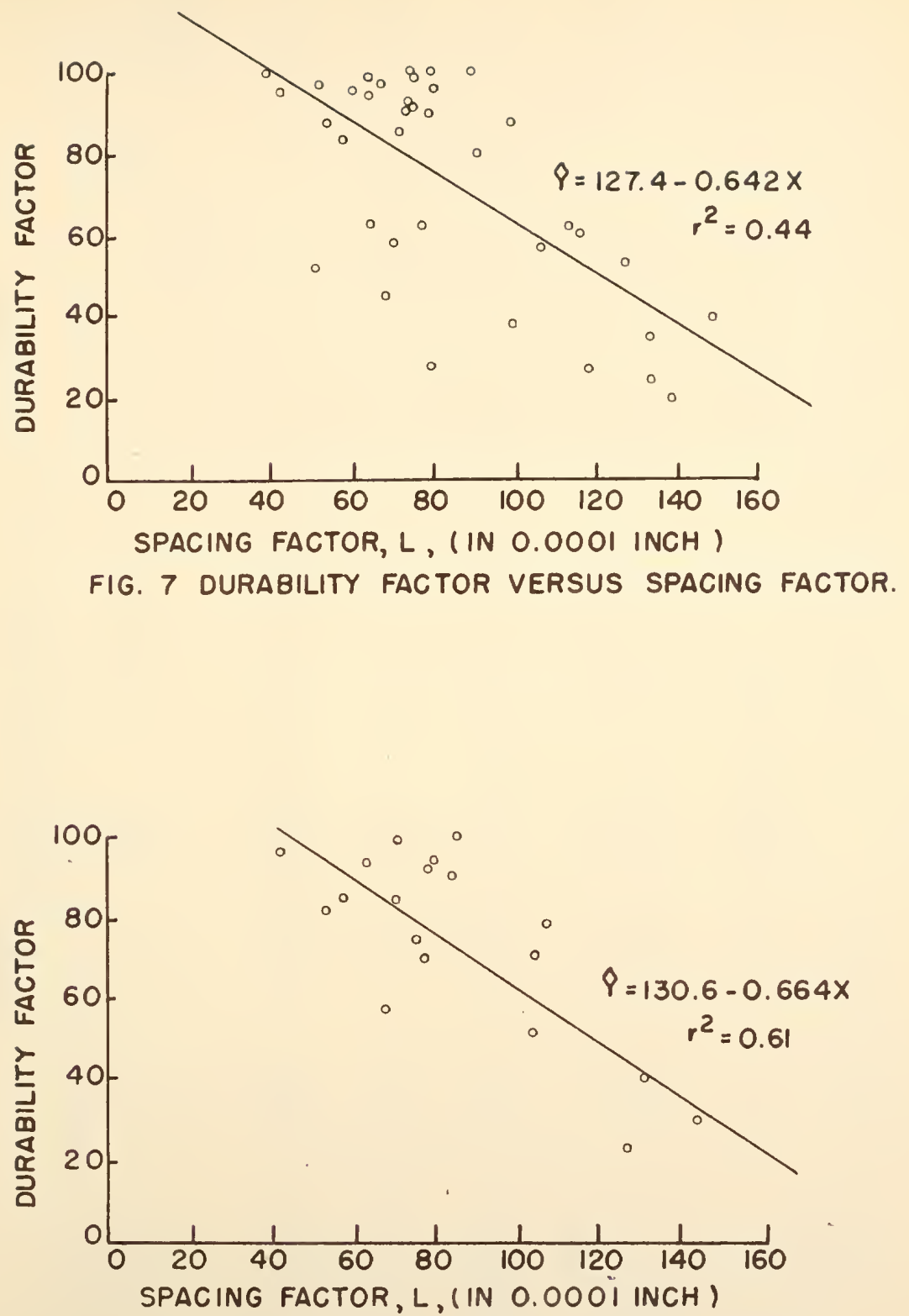

FIG. 8 DURABILITY FACTOR VERSUS SPACING FACTOR AVERAGE VALUES FOR MIXES 


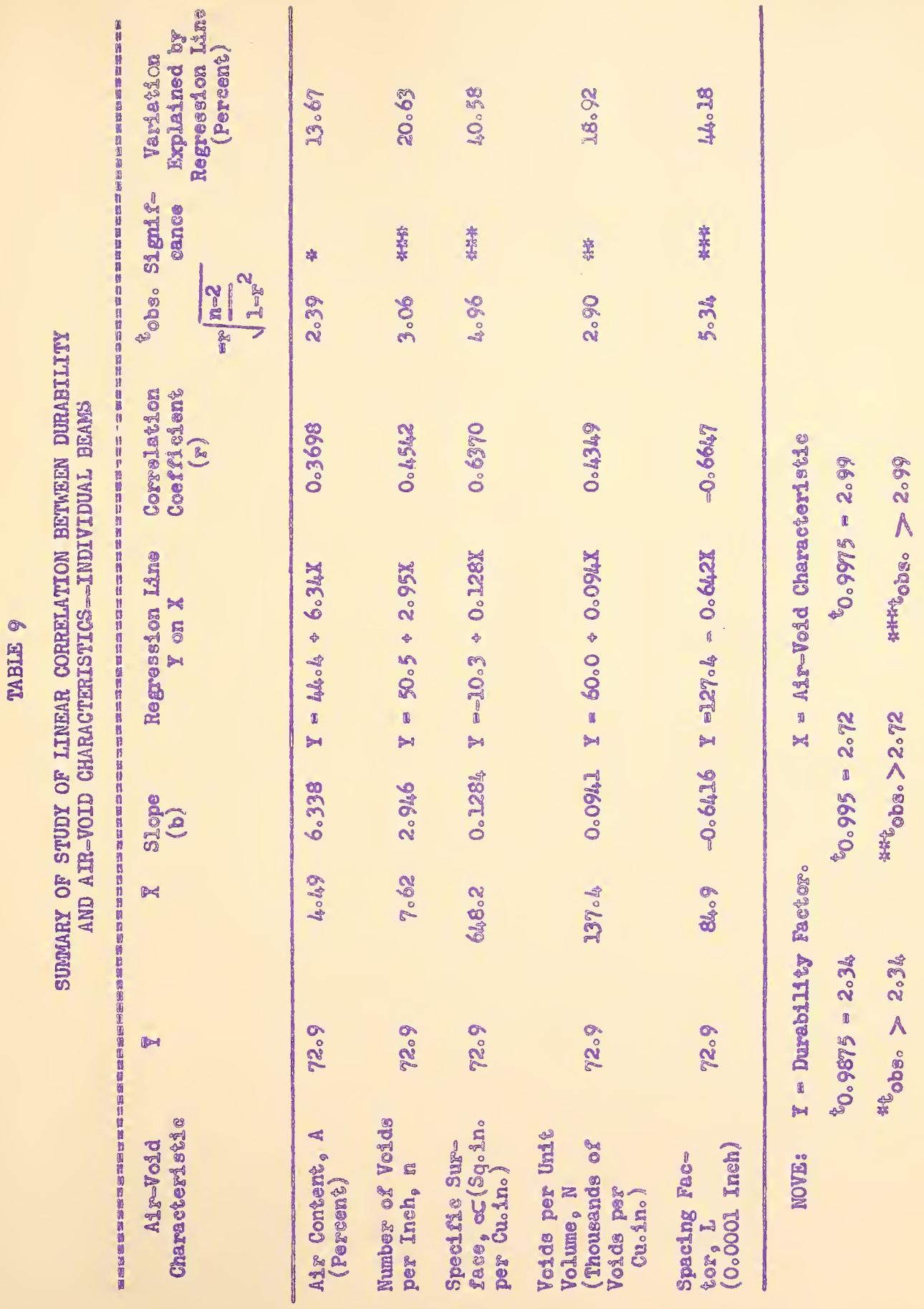


Linear Correlation-Average Values for each Mix

In order to study correlation between durablilty and air-vold characteristics on a mix basis an anglysis was made using the average values for each mix. Since froes -and-thaw data were avallable on three beams from each $m i x$, the durability factor for each mix wa taken as the average of the three beams. Average values for the durability factor and air-vold characteristics for each mix aro given in Table 10。 The value for each air-vold characteristic 18 the average for the two beams from the values given in Table 8. The rogults of the corralation study are sumarizod in Tablo 11 .

\section{Discuselon of correlation Studies}

The graphs of the curability factor plotted againgt the five alre vold characteristics (FIgures 3 through 7) show considerablo scatter。 Some of this scatter would be expected to result from the coarse-aggregate varlable. Inspection of the scatter diagrams alone would lead one to conclude that little correlation exists between the total alr content and durability for the beans examined in this study. In the past the total air content has been the airovold characteristic most used in determining the air requirements for frostoresistant concrete。

The airovold characteristics (specific surface and spacing factor) which are computed from equations containing both atr content and number of volds per Inch show the smallest amount of scatter. This indicates the importance of the interaction of these two characteristics in producing durable concrete. Inspection of Tables 9 and 11, also, shows the importance of the interaction of alr content and number of volds per inch in producing durable concrete. The spociflc surface and vold spacing factor give considerably higher correlation coefflcients than the other three characteristics, 


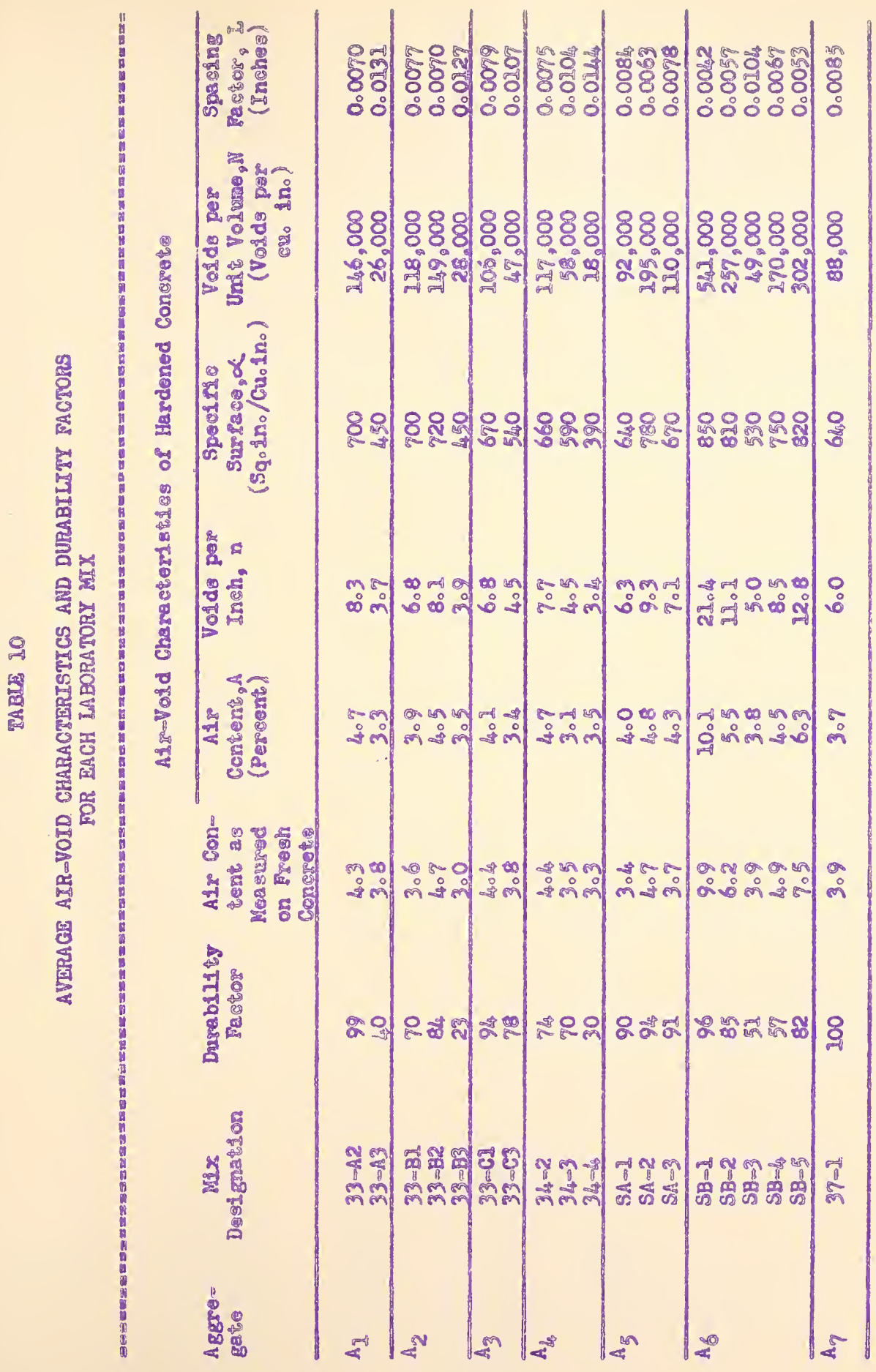




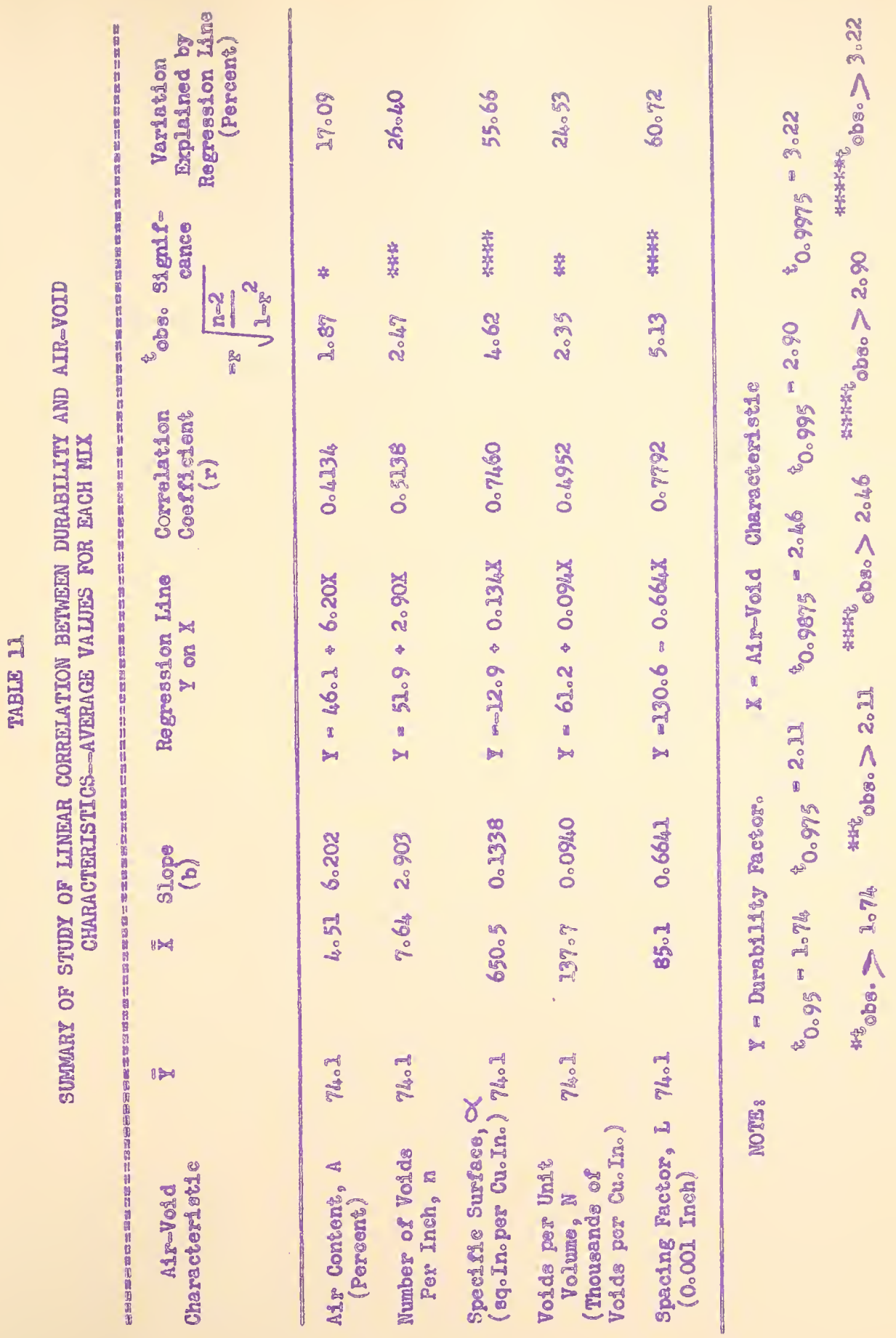


Tables 9 and 11 show that the correlation coefficient obtained using the average values for each mix is noticeable higher for each alr-vold characteristic than the corregponding value computed from the data for individual beams. This resuits from eliminating the large differences in durability between beams within the same mix by means of averaging the individual values. A large amount of this dife ference in durability within a mix can be attributed to the coarso aggregate in that differences in the combinations of deleterious pars ticles in the beams results in variations in durability。

Table 9 shows that 44 percent of the variation in durability can be attributed to differences in vold spacing based on the data for Individual beams while Table 11 shows a corresponding value of 61 perc cont using average values for each mix. In Figure 8 durablilty factor is plotted against void spacing using the average mix values, Comparison with Figure 7 shows considerable reduction in scatter when mix values are used。

Although there may be a better way to express the sjze and distribu= tiors of the air volds in portland cement paste than the spacing factor usad in this study, the results of the correlation studies emphasize the Importance of size and distribution in producing frost-resistant concrete. 


\section{SUMMAR OF RESULTS}

The results of the work completed in this investigation may be summarlzed in the following manner.

1. The measurement by the linear traverse technique of air cono tent and number of rolds per inch of a particular beam may be considered as one long traverse without regard to the position or length of the in dividual traverses, The standard orror of the mean is approximately the same ( 0.3 for the beams examined in this study) whether four ${ }_{2} s 1 x^{\circ}$, eight-s or ten-1nch traverses are used as long as the tota? length of the traverses is the same,

2. For the beams examined in this study, the selection of 200 Inches of traverses gave values for the air content within $\$ 0.5$ percent of the true valuo and the number of volds per inch within $\$ 0,5$ vold per inch of the true value at the 90 percent confidancs loved,

3. The accopted theoretical explanation of the action of entrained air in producing frost-resistant concrete denonstrates the importance of the elze and diatribution of the air volds. The correlation studies of the relationship between each of the air-vold characteristics and durability show the vold spacing factor to be most highly correlated with durability fastor. Using the data on individual beams, 44 percent of the differences in durability could be explained by the differences in the vold spacing factor. Ueing average values for each mix, 61 percent. of the differences in durability could be explained by differences in the vold spacing factor, Thus, this investigation essentielly gubstantiates the theory:

4. The speciflc surface was almost as highly correlated with durability as the void spacing factor with 41 percent of the variation in 
durabilfty baing explatned by the differences in the spectic aurfare when the data on the indiplual beams wered used. Using average values for each mix 56 percent of the variation in dureblilty coutd be as. platned by difforences 1r the specilic suriace

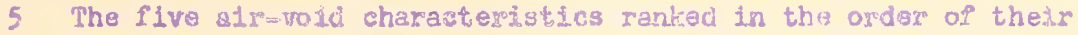
correlation with durability beginning with the one showing the best cor relation are: (a) spachise, factor (b) speclific aurfaca, (c) number of volds per dnch, (d) hypothetical number of volds por cubte inch, and (0) total air content.

6. Since the specficc surface was almost as highly correlated with ourability factor as the roid spacing factor either of theso two charac teristics s.s probably a satisfactory guidefor deternintng the air re guirements for frret=resistant conerete The correlation betweon aach of these two characteristics and curability was found to be highly 81 gnificant at the 9975 percent confidence level. 
The author wishes to expross his gincer'e apprecistion to the following etaff menbers of Purdue Universty: Prefossor K. B Woods

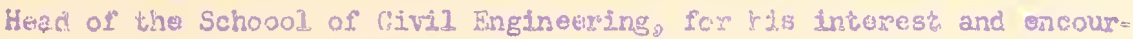
agement; Prafessor $P$. E. IrIck for guidance and acivice in all the statistileel aspects of the study: and Frofessor J F. Mclaughlin for his many helphul suggestions and for reviswing tho mamseript. The euthor

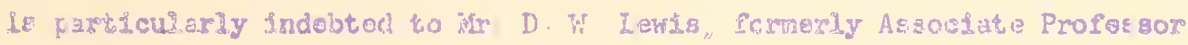

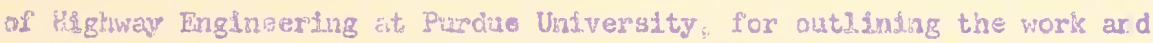
302 coting the beame to to axanined and for his guldance, encouragement, ane hotpful critgcisn. Dr, Is S. Brown of the Research and Developmert Laboratortes of the Port Iand Cameni Assoctation is due epecial mentior. for his helpful adylcs cn the use of the linear traverso tochnique anc. bs derconstration of the oquiprent 3nd procendures used in the PCA Laboratiogstes 


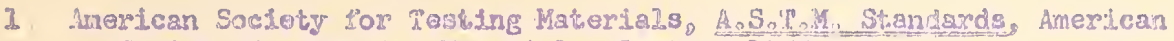
Socioty for Tosting Meteridalo, Part 3 \& 1955;

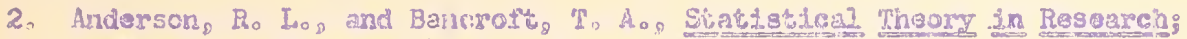

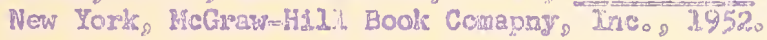

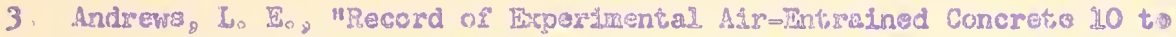

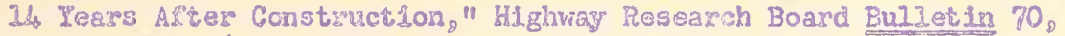
Pubiscation 261, 1953

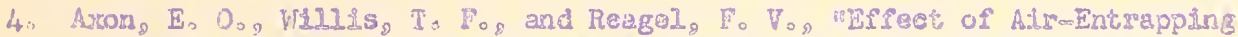

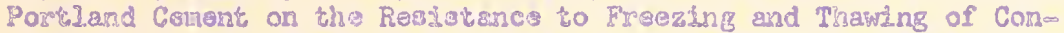

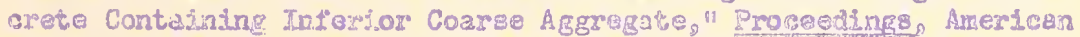

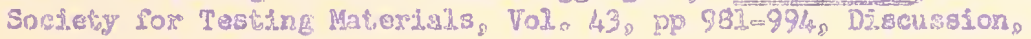
$\mathrm{pp}, 995=2000,1943$.

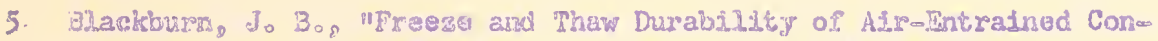

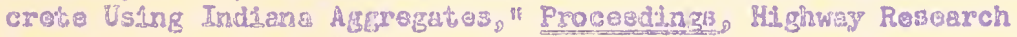
Board, Volto 28, PF, 171-194, 1948。

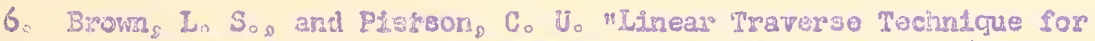

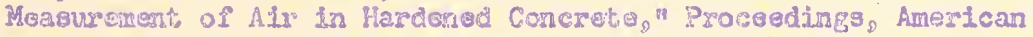
Concrote Institute, Vol. 47, ppo117-123, 1951

7. Bugg, SoLon Mifect of Air Entraiment on the Durability Character-

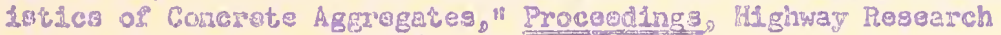
Bo2rd, Vol. 27, po. $156-169$, 1.94\%。

8. Discos, $W,\}_{0}$ and Masser, $F \circ J_{8}$ J

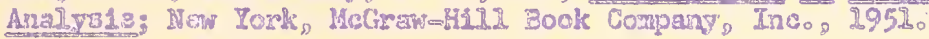

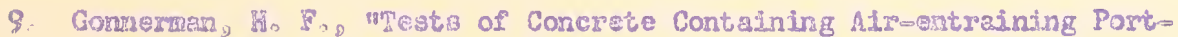
Lard Ceraents or Atroertiraining Materials Added to Batch at Mivor" Proceosings, Arexican Conarato Institute, Volo 40 , pp $447-508$, गิ944?

20. Jackson, T. Hn, "LonE-Timo Study of Cment Pox formance In Concrete, Procesingse, Anerican Concrete Institute, Vol, 52, pp. 159-193, 1956 .

11. Rloger, Paul "iffoct of Entrained Air on Strength and Durability of Concrete Hade with Vardous Maximuan Sires of Aggragato, 8

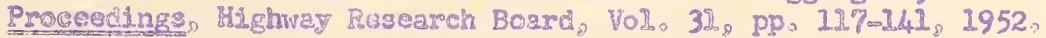

12 Lincoln, Fo $C_{2}$ and Felis, H. Log Mhe Dotorination of the Relative Volumes of the Componenty of Rocks by Mensuration Methods," Econcmic Geckogy, Vol, 8, pp, 120 139,2913 ,

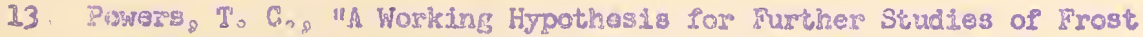
Rasistance of Concrate "Proceedings, Anerican Conerete Insti= tuto, Vol. 4h, pp 245-272, 19450 
14 Powers, T. C " "The Alr Requirement of Frost-Resistant Concrete, "N Procedings, Mighway Research Board, Vol. 29, pp 184-202, 19490

15. Powers, $\mathrm{x}, \mathrm{C}$, and Holmuth, R. A, "Theory of Volume Changes in Haxdened Portland-Coment Paste Duxing Frearing, "Proseedings, HIghway Roserrch Board, Vol, 32. pp, 285-297, 2952.

26. Powers, T. Co "Vold Spacing as a Basis for Producing Air-Entriainad Conerato ${ }^{33}$ Proceedings, Amedican Concrete Institute Vol. 50, pp. $741=760,1954$.

17. Rexford, E, P. Discusston of a paper by Goorge Verbock: "The Camera Luclda Mathod for Meesuring Air Votás in Mardened Con=

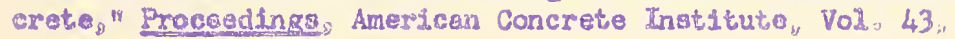
pp. $1040-1 \times 2040=4.1947$

18 Roeiwal, August, "Uaber geometrischa Gestoinanalyai $a_{5}$ EIn etnfachar Wog mux zifformassigen Festgtollung dos Cuantitatarorhaltnisses

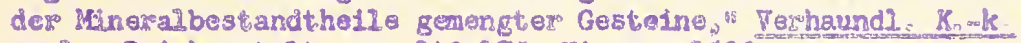
goolo Pelcheastalt, pp. 143-175, VLenna, 1898

19. Shand, S. Jog "A Recording Mfcrometer for Geometrical Rock Anslygis "." sournal of Geologr, Vol, 24, pp, 394-40\%, 1916.

20. Verberk, G, J, "The Camera Luctda Method for Measuring A1x Vodd In Hardened Concret, $\theta_{i}$ Propoedinge Anerican Conerete Inst1tute, Vol. $438 \mathrm{pp}, 1025-1039,1.947$

21. Walker Stanton "Resistance of Conerete to Freezing and Thawing as Afferted by Agrregates "Clrcular 26, National Sand and Gravel Association, 1944 .

22. Warren, Curt1s, "Deternination of Propertles of Air Voids in Con erete, H1ghway Rosearch Board Sullotin 70, Publication $26 \mathrm{l}$ 1953:

23. Wentworth, $C, R_{0}$, "An Improved Recording Wicrometer for Rock Anal. 7818 , 18 journal of Geolog: Vol. 31 , pp. 228-232, 1923.

24: Willis, T, F, Dlscussion of a paper by $T$, $C$. Poweris: "Ihe Air Regulrement of Frostareslitant Concrete " Proceeding $s_{2}$ Highway Research Board, Vol, 29, pp, 203.211, 1949.

25. Wuerped, Co E。 "Laboratory Studjes of Concret Contalning Adr. Entrainine Adnixtures " Pnoceedings, American Concrate Instix tute. Vol. $42, \mathrm{pp}, 305=359,1946$. 

